\title{
Inverse Modeling of Particulate Organic Carbon Fluxes in the South Atlantic
}

\author{
R. Schlitzer ${ }^{1 *}$, R. Usbeck ${ }^{1}$ and G. Fischer ${ }^{2}$ \\ ${ }^{1}$ Alfred Wegener Institute for Polar and Marine Research, Columbusstrasse, \\ D-27568 Bremerhaven, Germany \\ ${ }^{2}$ Universität Bremen, Fachbereich Geowissenschaften, Postfach 3304 40, \\ D-28334 Bremen, Germany \\ *corresponding author (e-mail): rschlitzer@awi-bremerhaven.de
}

\begin{abstract}
The biological production of particulate material near the ocean surface and its subsequent remineralization during sinking and after deposition on the seafloor strongly affect the distribution of oxygen, dissolved nutrients and carbon in the ocean. Dissolved nutrient distributions therefore reveal the underlying biogeochemical processes, and these data can be used to determine rates of production, remineralization and accumulation with the aid of inverse techniques. Here, an ocean circulation, biogeochemical model that exploits the existing large sets of hydrographic, oxygen, nutrient and carbon data is presented and results for the export production of particulate organic matter, vertical fluxes in the water column, and sedimentation rates are presented. In the model, the integrated export flux of particulate organic carbon (POC) in the South Atlantic amounts to about

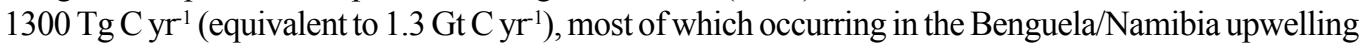
region and in a zonal band following the course of the Antarctic Circumpolar Current (ACC). Remineralization of POC in the upper water column is intense, and only about $7 \%$ of the export reaches a depth of $2000 \mathrm{~m}$. Comparison of modeled particle fluxes with sediment trap data suggests that shallow traps tend to underestimate the downward flux, whereas the deep traps seem to be affected by the lateral input of material and apparently overestimate the vertical flux. These findings are consistent with recent radionuclide studies. The rapid degradation of POC with depth produces geographical patterns of $\mathrm{POC}$ fluxes to the seafloor and $\mathrm{POC}$ accumulation in the sediment that are very different from the pattern of surface productivity, because of the modulation with varying bottom depth. Whereas there is significant surface production in deep-water, open-ocean regions, the benthic fluxes occur predominantly in coastal and shelf areas.
\end{abstract}

\section{Introduction}

Biogeochemical processes in the ocean act as a downward pump (Volk and Hoffert 1985) that produces low concentrations of nutrients and carbon in surface water and high values below. The low surface concentrations are caused by biological production in the sun-lit euphotic zone, which utilizes the dissolved nutrients in the formation of particulate material (primary production $\mathrm{PP}$ ). One fraction of the particles sink out of the euphotic zone (export production EP), thereby effectively removing nutrients and carbon from the surface layer. In intermediate, deep and bottom layers nutrients are subsequently returned to the dissolved pool by particle decomposition (remineralization) while they sink in the water column, or after they settle on the seafloor. The decrease of surface water carbon concentrations due to the biological pump is a crucial factor that affects surface water $p \mathrm{CO}_{2}$ values and ultimately controls the air-sea $\mathrm{CO}_{2}$ exchange and atmospheric $\mathrm{CO}_{2}$ concentrations.

Because of the large potential impact on the atmospheric $\mathrm{CO}_{2}$ budget and global climate, deter- 
mining the strength of the biological pump, e.g. the magnitudes of export production and downward particle fluxes, has been a high-priority research goal for a long time. Three main experimental approaches have been developed: (1) the direct measurement of the vertical particle fluxes with moored or drifting sediment traps (Honjo et al. 1982; Wefer et al. 1982; Fischer et al. 1988; Deuser et al. 1995; Fischer et al. 1996; Fischer and Wefer 1996; Neuer et al. 1997; Fischer et al. 2000), (2) the estimation of primary or export production from surface-water chlorophyll concentrations obtained from satellites (Longhurst et al. 1995; Antoine et al. 1996; Behrenfeld and Falkowski 1997; Arrigo et al. 1998; Laws et al. 2000), and (3) the determination of oxygen utilization rates in tracer-dated thermocline, intermediate and deep water masses (Jenkins 1982; Jenkins and Goldman 1985; Jenkins 1987; Broecker et al. 1991).

Sediment trap measurements are point measurements and strongly influenced by the large temporal and spatial variability of production and particle flux events. Therefore, mean export production rates for larger regions or on global scale, as required for climate studies, are difficult to obtain from trap data. In addition, results from shallow traps (needed to estimate the export flux) have been questioned because of the suspected low trapping efficiency (see below). Satellite observations provide a global view, however, estimates of primary or export production from satellites have large uncertainties, because the conversion of chlorophyll concentrations into productivity rates and vertical particle fluxes is difficult and only relies on a very limited number of regional calibration studies. Furthermore, the optical sensors of the satellites only probe a thin surface layer of the ocean and deeper chlorophyll patches often found by towed instruments are missed. Recently, a systematic comparison of various satellite productivity algorithms has revealed significant random and systematic differences (Campbell et al. 2002).

Here, a very different approach is taken to estimate marine export production and downward particle fluxes through the water column and to the seafloor. The basic principle was proposed and applied by Riley (1951), who realized that the observed oxygen, nutrient, and carbon distributions in the ocean can be used to quantify the biogeochemical processes that shape the distributions. To give an example, Figure 1 shows phosphate and oxygen distributions along a meridional (AJAX; Nierenberg and Nowlin (1985)) and zonal (WOCE A7; WOCE Data Products Committee (2000)) section in the South Atlantic. In tropical and subtropical waters, biological consumption leads to a draw-down of surface phosphate to almost non-detectable levels. As shown in Figure 1a, this nutrient depleted surface layer is very thin $(<100 \mathrm{~m})$, except in the center of the subtropical gyre (ca. $30^{\circ} \mathrm{S}$ ) where low-nutrient waters are found down to about $400 \mathrm{~m}$ due to Ekman pumping. In the sub-Antarctic and Antarctic zone, surface phosphate concentrations are much higher, but significant nutrient draw-down in a very thin surface layer seems to occur in this area as well, as indicated by the large vertical phosphate gradient found south of about $50^{\circ} \mathrm{S}$ (Figure 1a). Below the depleted surface layer, phosphate concentrations increase drastically with depth and reach maximum levels at about $500 \mathrm{~m}$. These maximum phosphate concentrations a are most pronounced in the eastern tropical and subtropical Atlantic where biological productivity is high, and they are associated with strong oxygen minima (Fig. 1b). The anti-correlation between oxygen and phosphate provides additional evidence that the subsurface phosphate and oxygen signals are caused by biogeochemical processes, e.g. remineralization of sinking particulate material that brings nutrients back into solution and at the same time consumes dissolved oxygen.

It is important to note that the biogeochemically induced features of the nutrient, oxygen and carbon distributions have large amplitudes, and that these structures are very well resolved by the large amount of available data. Comparisons of repeated observations as long as 60 years apart show that these features are quite stable, and temporal changes are quite small even on decadal time-scales (Schlitzer 2000). This is in contrast to the large spatial and temporal variability seen in productivity maps from satellites and in sediment trap time series, and suggests that the surface nutrient depletion and the sub-surface nutrient maxima as well as the pronounced shallow oxygen minima are the integrated and averaged response of many bloom 

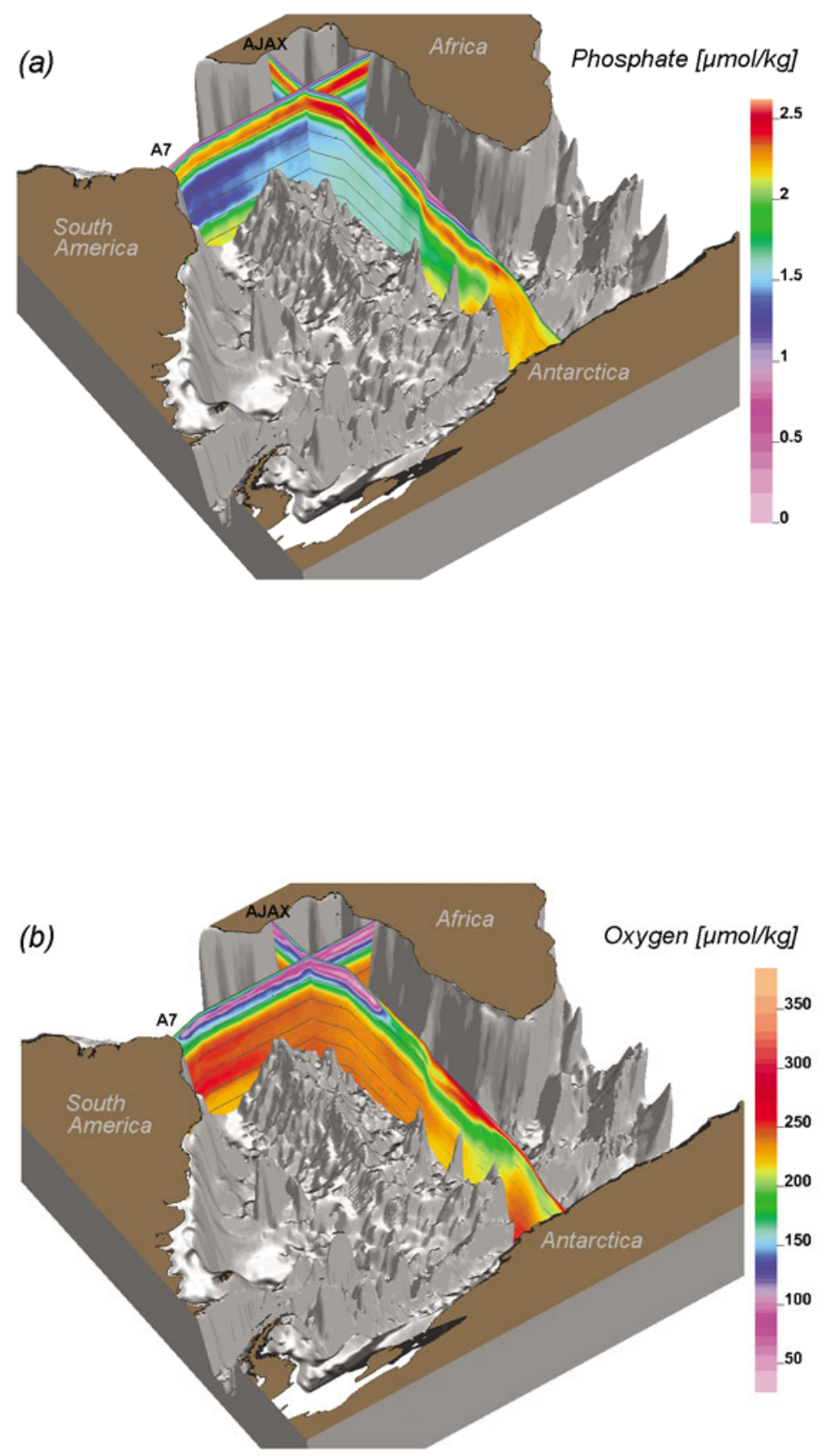

Fig. 1. Three-dimensional display of a) phosphate and b) oxygen distributions along two sections in the South Atlantic. Dark lines indicate depth levels in $1000 \mathrm{~m}$ intervals. 
and flux events from many years. Therefore, utilizing dissolved nutrients, carbon and oxygen fields promises to yield large-scale and long-term productivity and downward carbon flux estimates - quantities needed for global budget calculations and difficult to obtain from satellite or sediment trap observations alone.

In addition to the influence of biogeochemical processes on marine nutrient, carbon and oxygen fields, these distributions are also strongly affected by the circulation and water mass transport. This can be clearly seen in the western part of the A7 section in the Brazil Basin, where the vertical layering of waters with high phosphate concentrations at a depth of about $800 \mathrm{~m}$, low phosphate levels between about 1500 and $4000 \mathrm{~m}$, again high values below $4000 \mathrm{~m}$, and near the bottom reflect the meridional overturning circulation consisting of northward moving Antarctic Intermediate Water (AAIW) and Antarctic Bottom Water (AABW), with southward flowing North Atlantic Deep Water (NADW) in between. A successful determination of biogeochemical flux rates from dissolved nutrient and oxygen fields therefore also requires to take physical transports into account. This is addressed by the approach described below.

In contrast to nutrient simulations using forward models, the estimation of physical or biogeochemical rate constants from concentration data is commonly referred to as inverse calculations. Since Riley's (1951) work, the amount and quality of available data has increased tremendously, and advances in computer technology and numerical methods now allow detailed studies on a global scale dealing with many particle species and the large variety of measured properties simultaneously.

The model strategy described below employs the adjoint method to determine flows (physics) and production as well as remineralization parameters (biogeochemistry) that explain the global hydrography and the measured concentration fields of dissolved nutrients, carbon and oxygen best. The problem is formulated as a constrained optimization and the solution is found iteratively. It should be noted that in contrast to ecosystem models (Fasham et al. 1990) that attempt to describe the complicated interactions and feedbacks of biologi- cal food-webs and community structures explicitly, in the present case the processes leading to the production, export and subsequent remineralization of particles are not resolved by the model, but parameterized as rate constants to be determined by the model. The unknown production or remineralization rates are only constrained by the requirement to reproduce the observed property distributions realistically. As described below, empirical flux-depth relations are applied, but biogeochemical a priori information about the underlying processes is not incorporated.

In this paper we present results from a model setup that includes particle production in the surface layer, remineralization in the water column and at the seafloor, and accumulation of material in the sediment. Input of material from rivers is included to account for losses in the sediment. Results from two model runs that account for dissolved organic matter and $\mathrm{N}_{2}$-fixation and denitrification effects in the South Atlantic are also included. One of these experiments is further constrained by fitting it to observations of natural radiocarbon and chlorofluorocarbons (CFC). Maps of organic carbon export fluxes, fluxes towards the bottom, and sediment accumulation rates are shown for the South Atlantic, and regional integral flux estimates are given. In addition, a detailed comparison of model particle fluxes with sediment trap measurements is included.

\section{Inverse Model}

As described above, determining particle fluxes and near-surface production rates from nutrient concentrations requires a biogeochemical model that also includes the ocean's 3-D circulation. Here, the global model of de las Heras and Schlitzer (1999) and Schlitzer (2000) is used that has already been fitted to global hydrographic, nutrient and oxygen fields. The general model strategy is based on Schlitzer (1993), and more details can be found there and in Schlitzer (1995, 1996, 2000, 2002). In the following, the model setup is briefly described and then the extensions with respect to biogeochemical cycles are explained.

Overall goal of the model calculations is to find a steady global ocean flow field (representing the 
climatological mean circulation) and mean export production of particulate organic carbon (POC) as well as POC fluxes throughout the water column and to the seafloor. The model run described here also includes the accumulation of organic material in the sediment. To be considered as optimal, the calculated velocities must have velocity shears that are close to geostrophic shear estimates and simulations of hydrographic and nutrient distributions must reproduce the respective observations accurately (see Schlitzer 1993 for more details). The adjoint method provides the means that drive the model to the desired state (see Schlitzer 2000 for more details).

The model is of global extent and uses a nonuniform grid with horizontal resolution ranging from $5 \times 4$ degrees longitude by latitude in open ocean areas to $1 \mathrm{x} 1$ degrees in regions with narrow currents (Drake Passage, Atlantic part of the Antarctic Circumpolar Current, Indonesian and Caribbean archipelagos), along coastal boundaries with strong currents (Florida Current, Gulf Stream, Brazil Current, Agulhas Current, Kuroshio), over steep topography (Greenland-Iceland-Scotland overflow region) and in areas with pronounced coastal upwelling or downwelling (Fig. 2a). In all cases the refinements are implemented in the direction of the strongest property gradients (usually perpendicular to fronts and currents) to better trace changes in ocean properties.

The model has 26 vertical layers, with thickness progressively increasing from $60 \mathrm{~m}$ at the surface to approximately 500 meters at $5000 \mathrm{~m}$ depth. Realistic topography is used, based on the U.S. Navy bathymetric data and averaged over gridcells. Model depths over ridges and in narrow channels are adjusted manually to respective sill or channel depths. The model has three open boundaries, along which ocean properties and transports are prescribed in each model layer. They are located at the exit of the Mediterranean Sea, Red Sea and Persian Gulf. These three marginal seas are not modeled explicitly, but their impact on the global circulation is taken into account.

A schematic diagram of a vertical model column extending from the sea surface down to the respective bottom depth is shown in Figure $2 b$. Model property values are defined at the centers of the grid-boxes whereas flows are defined on the interfaces (Arakawa C-grid). Formation of particulate material is occurring in the top two model layers with the top layer contributing $75 \%$ and the second layer contributing $25 \%$ of the total production. The bottom of the second model layer is considered the base of the euphotic zone (here: $\mathrm{z}_{\mathrm{EZ}}=133 \mathrm{~m}$ ). Particle fluxes below the euphotic zone are assumed to decrease with depth according to

$j_{P}(z)=a \cdot\left(z / z_{E Z}\right)^{-b}$

This functional relationship is commonly used for the depth dependence of the flux of particulate organic carbon (POC) (Suess 1980; Martin et al. 1987; Bishop 1989). In (1) $a$ is the particle flux at the base of the euphotic zone, $z_{E Z}$, and represents the export production. The parameter $b$ determines the shape of particle flux profile and thus controls the depth of remineralization. Large values for $b$ correspond to steep particle flux decreases and thus large remineralization rates just below the euphotic zone, whereas values for $b$ close to zero result in almost constant particle fluxes independent of depth, with little remineralization in the water column and most of the particle export reaching the ocean floor.

The particle flux to the bottom is given by $j_{P}\left(z_{b}\right)=a \cdot\left(z_{b} / z_{E Z}\right)^{-b}$, where $z_{b}$ is the bottom depth. In the model that includes sedimentation, a fraction of this flux reaching the bottom- is buried in the sediment $j_{B}=s \cdot j_{P}\left(z_{b}\right)$ (with $0 \leq s \leq 1$ ), while the remainder is remineralized in the bottom box. The globally integrated loss of material to the sediment is compensated in the model by input from rivers. Here, the thirteen largest rivers are considered. The sources are located in the surface layer of the model columns closest to the respective river mouths, and the strength of the material sources is set proportional to the water discharge and nutrient concentrations of the respective river (Lerman 1980; Berner and Berner 1996; Usbeck 1999). In the model runs without sedimentation all material reaching the seafloor is remineralized there.

Export production $a$, remineralization scale height $b$, and sedimentation fraction $s$ may vary 
(a)

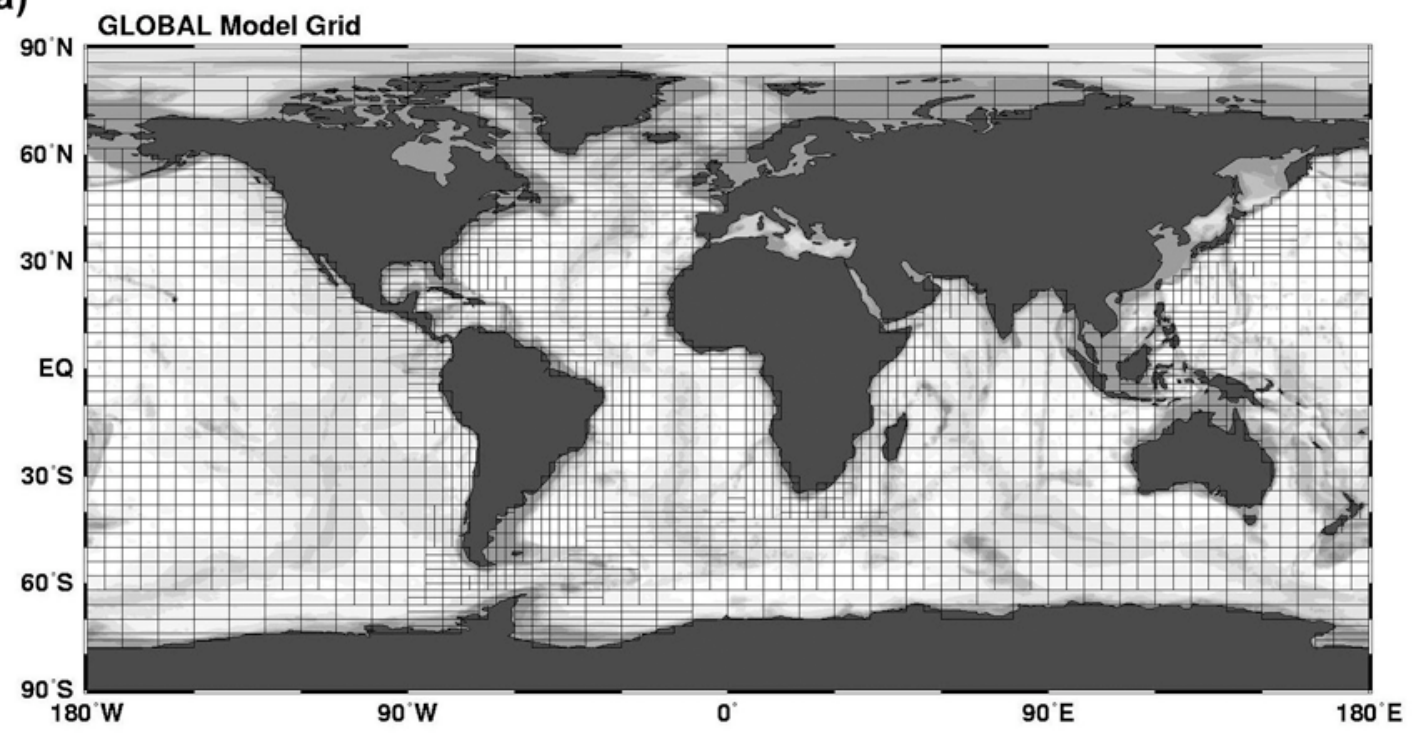

(b)
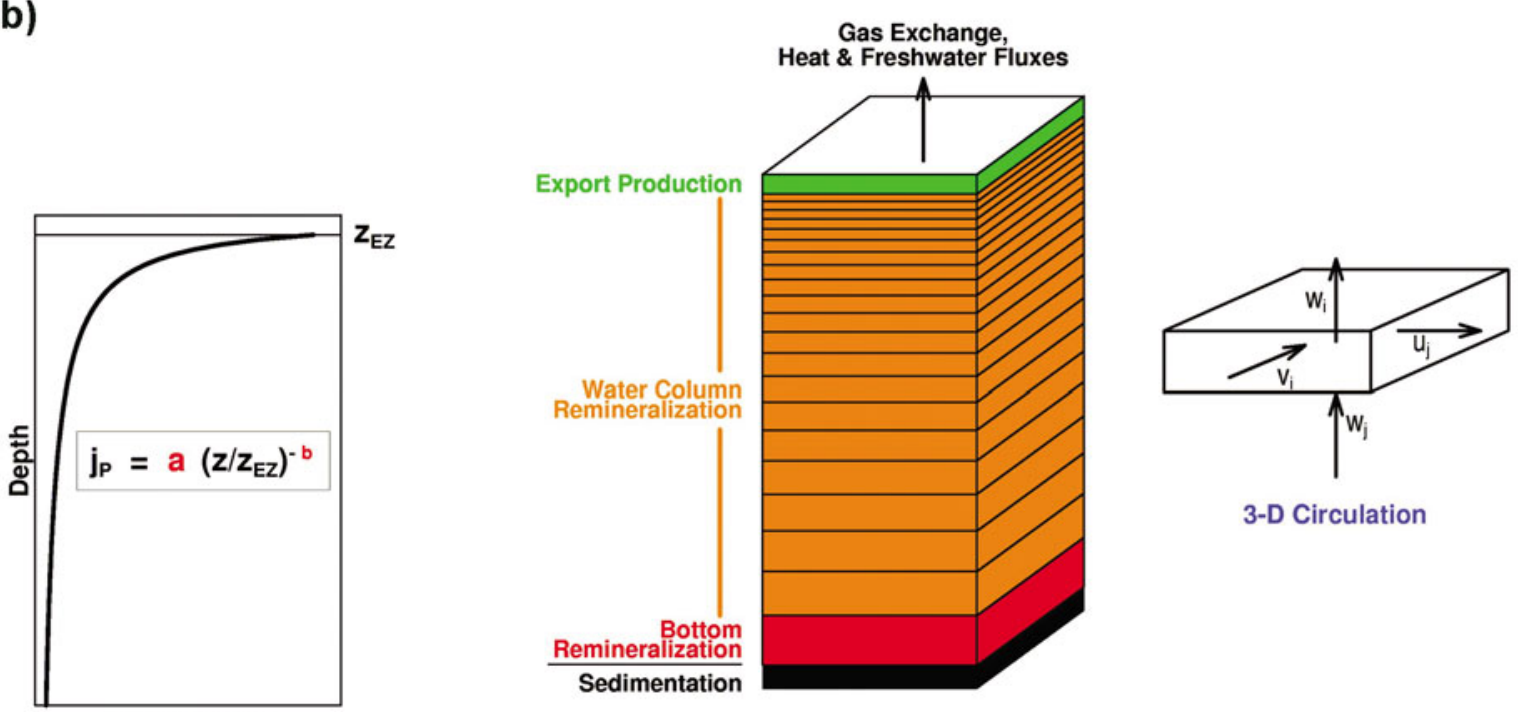

Particle Flux

Fig. 2. Horizontal a) and b) vertical model grid and definition of model parameters. 
from grid column to grid column. Note that these parameters are not formally dependent on environmental factors such as nutrient availability, light intensity or density stratification, as implemented in other biogeochemical models (Maier-Reimer 1993; Yamanaka and Tajika 1996), but can be freely chosen by the model to achieve optimal agreement with measured oxygen, nutrient and carbon fields.

The computational strategy is explained in detail in Schlitzer (2000) and Schlitzer (2002), here only a brief summary will be given. The horizontal model flow field is initialized using geostrophic velocities calculated from original hydrographic data. Following suggestions from the literature (Reid 1986; Whitworth and Nowlin 1987; Rintoul and Wunsch 1991; Rintoul 1991; Reid 1997) the reference level for the geostrophic calculations varies geographically: $z_{r}=1500 \mathrm{~m}$ north of $25^{\circ} \mathrm{S} ; z_{r}=3800$ $\mathrm{m}$ south of $45^{\circ} \mathrm{S}$; linear transition between $25^{\circ} \mathrm{S}$ and $45^{\circ} \mathrm{S}$.

The initial export fluxes of POM $a$ are derived from the productivity map of Berger (1989), and the initial values of the remineralization parameters $b$ are set to 1 (Suess 1980). Using this set of initial independent parameters, model vertical velocities as well as model fields for temperature, salinity, oxygen phosphate, nitrate, total inorganic carbon and alkalinity (dependent parameters) are calculated by applying steady-state conservation equations for mass, heat, salt, oxygen, nutrients, carbon, and alkalinity, respectively. This step of calculating the vertical velocities and model property fields is commonly referred to as a simulation.

Once calculated, the simulated property distributions can be compared with measurements. Usually, this model/data comparison is done subjectively, and attempts are made to correct potential causes for model/data misfits by modifying the velocity and biogeochemical parameters and then running new simulations. While this approach usually is successful for box-models with a limited number of parameters, for large 3D models like the present one, the manual adjustment of parameters is impractical and in most cases does not lead to desired improvements.

The so-called adjoint method (Hestenes 1975; Thacker and Long 1988; Schlitzer 2000) is an alternative to manual parameter-tuning, and allows treatment of optimization problems with a large number of adjustable parameters, like the present one. Here the evaluation of model/data misfits is performed automatically by using a suitably formulated cost function (see Schlitzer 2000 for a detailed discussion of cost function terms). A twin-model of the simulation step (the adjoint model) "learns" from the structure in the misfits and modifies the independent parameters (flows and biogeochemical parameters) in a systematic way that guarantees a better model/data agreement in the next simulation. By running the forward/adjoint steps repeatedly, the model is driven closer and closer to the observations. The calculations are terminated when the decrease of the cost function (improvement) per iteration is smaller than a pre-defined limit.

Because of the huge computational requirements of the optimization procedure described above, and because of a general lack of biogeochemical data that fully describe the seasonal cycle, the present model is formulated as a steadystate, annual-mean model. The optimized model flow field and particle flux patterns represent longterm means over the time periods covered by the data that are used by the model (ca. 1939 -2002), and no attempt is made to resolve time-dependent and sporadic events, such as eddies or individual bloom events.

In the following, results from three different model runs are presented (Table 1). Run A includes accumulation of material in the sediment, but neither dissolved organic matter cycling nor $\mathrm{N}_{2}$ fixation or denitrification. This experiment is fitted to global ocean temperature, salinity, oxygen, dissolved nutrient and carbon data and represents the reference experiment from which most conclusions are drawn here.

Experiments B and C disregard loss of material in the sediment but include cycling of semi-labile dissolved organic matter (Kirchman et al. 1991; Hansell and Carlson 1998), and $\mathrm{N}_{2}$ fixation and denitrification as sources and sinks for nitrate. Nitrogen fixation and denitrification rates are not derived directly from measurements, but are specified using information on globally integrated fixation rates from the literature (Codispoti and Christensen 1985; Gruber and Sarmiento 1997). In the model, nitrogen fixation is evenly distributed over 


\begin{tabular}{|c|c|c|c|c|c|c|}
\hline Experiment & \multicolumn{3}{|c|}{ Processes Included } & \multicolumn{3}{c|}{ Data Used } \\
\hline & sedimentation & $\begin{array}{c}\text { dissolved } \\
\text { organic matter }\end{array}$ & $\begin{array}{c}\mathrm{N}_{2} \text { fixation, } \\
\text { denitrification }\end{array}$ & $\begin{array}{c}\mathrm{T}, \\
\mathrm{S}\end{array}$ & $\begin{array}{c}\mathrm{O}_{2}, \text { nutrients, } \\
\text { carbon }\end{array}$ & $\begin{array}{c}{ }^{14} \mathrm{C}, \\
\mathrm{CFC}\end{array}$ \\
\hline $\mathbf{A}$ & & & & & & \\
\hline B & yes & no & no & yes & yes & no \\
\hline C & no & yes & yes & yes & yes & no \\
\hline
\end{tabular}

Table 1. Model experiments used for the present study.

those surface areas where dissolved nitrate is lower

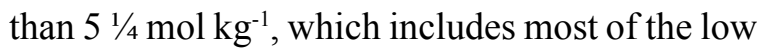
and mid-latitudes. Denitrification exactly matches total nitrogen fixation and is equally divided into water-column and benthic denitrification. The benthic denitrification is set to be proportional to the POC flux to the seafloor, and water-column denitrification is evenly spread over all volumes in which dissolved oxygen is below $201 / 4 \mathrm{~mol} \mathrm{~kg}^{-1}$. This places most of the denitrification in the $\mathrm{Pa}$ cific and Indian Ocean at a depth between 100 and $800 \mathrm{~m}$, which is in agreement with observational evidence (Codispoti and Christensen 1985; Codispoti et al. 1986; Howell et al. 1997).

Experiment $\mathrm{C}$ is fitted to natural radiocarbon data and chlorofluorocarbons (CFC) (WOCE Data Products Committee 2000) in addition to hydrography and dissolved oxygen, nutrients and carbon, as for the other runs. These experiments are performed to explore the range and uncertainties of model flux estimates. In most regions, reactive dissolved organic matter is confined approximately to the upper $200 \mathrm{~m}$ of the water column (Hansell and Carlson 1998; Anderson and le B. Williams 1999) and $\mathrm{N}_{2}$ fixation and denitrification are more important in the Pacific as compared to the South Atlantic. Therefore, experiment $A$ is considered a valid representation of the carbon cycle in the South Atlantic.

The automatic fitting procedure (adjoint model) described above has been applied successfully for all three experiments $\mathrm{A}$ to $\mathrm{C}$, and the overall agreement between model simulated fields and observations is excellent and much better (misfit between modeled and measured values is about one order of magnitude smaller) than in other global biogeochemical models (Maier-Reimer 1993; Sarmiento et al. 2000). In the South Atlantic, at a depth of $500 \mathrm{~m}$, where biogeochemical effects on dissolved nutrient and oxygen distributions are greatest (see Fig. 1), the mean model phosphate concentration is only $0.031 / 4 \mathrm{~mol} \mathrm{~kg}^{-1}$ higher than observed, and the root-mean-square (rms) deviation amounts to only $\pm 0.161 / 4 \mathrm{~mol} \mathrm{~kg}^{-1}$. For oxygen in the same region, the deviations are $-0.5 \pm 16^{1 / 4}$ mol kg-1 . Given typical measurement errors of 0.02 and $2 \frac{1}{4} \mathrm{~mol} \mathrm{~kg}^{-1}$ for phosphate and oxygen, respectively, the model misfits are considered to be small, and experiments A to $\mathrm{C}$ all explain the observed distributions realistically.

\section{Export of Particulate Organic Carbon}

Figure 3 shows the model export fluxes of particulate organic carbon in the South Atlantic that is required for the successful reproduction of the measured property fields. This plot is for experiment $\mathrm{A}$, but the geographical patterns as well as the magnitudes of the fluxes are similar for experiments B and C. According to the model, the downward carbon export in the South Atlantic predominantly occurs in two areas: (1) the Benguela-Namibia coastal upwelling region, and (2) a broad zonal band centered at about $50^{\circ} \mathrm{S}$ and roughly coinciding with the course of the Polar Front and the Antarctic Circumpolar Current (ACC). Here, the highest productivity is found in the western part, e.g. in northern Drake Passage, on the Patagonian shelf and eastward (downstream) over the North Scotia Ridge (ca. $\left.45^{\circ} \mathrm{W} / 53^{\circ} \mathrm{S}\right)$. Low export fluxes $(<1 \mathrm{~mol}$ $\left.\mathrm{C} \mathrm{m}^{-2} \mathrm{yr}^{-1}\right)$ are found in the center of the subtropical gyre at about $30^{\circ} \mathrm{S}$, where surface waters are 


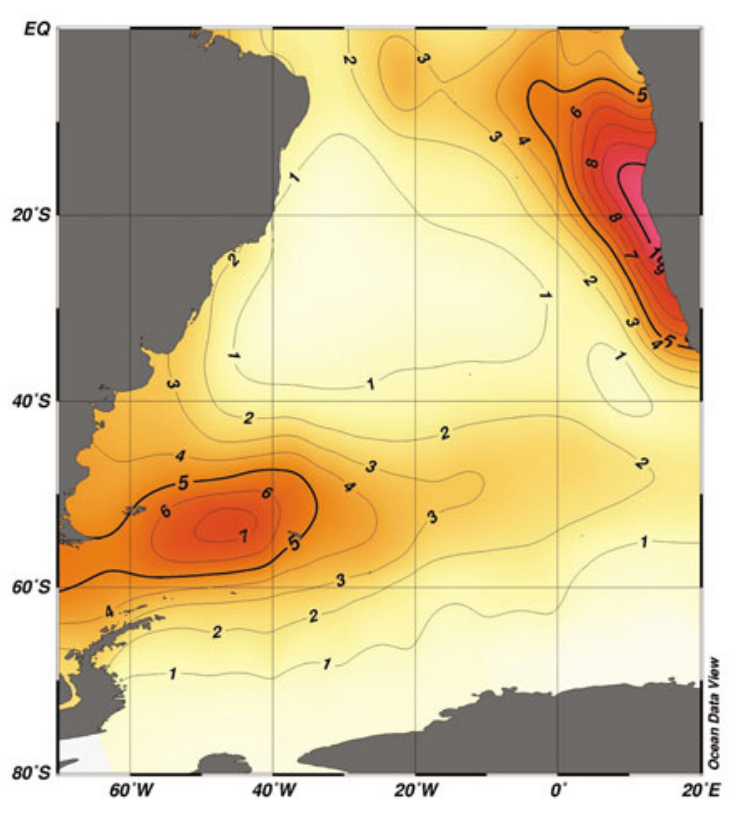

Fig. 3. Export flux of particulate organic carbon $\left[\mathrm{mol} \mathrm{C} \mathrm{m}^{-2} \mathrm{yr}^{-1}\right]$ in $133 \mathrm{~m}$ depth for the model including accumulation of material in the sediment (experiment $\mathrm{A}$ ).

nutrient-depleted (Schlitzer 2002), and in the Weddell Sea, where permanent or seasonal ice coverage and presumably the unavailability of micronutrients such as iron (de Baar et al. 1995) limit biological productivity. Given the high phosphate and nitrate concentrations in ACC surface waters $\left(\mathrm{PO}_{4}>1 \frac{1}{4} \mathrm{~mol} \mathrm{~kg}^{-1}\right.$; Schlitzer 2002), the export fluxes in the southwest Atlantic appear small compared to the Namibia coastal upwelling region. Again, iron limitation, strong vertical mixing and weak surface stratification are possible explanations for the relatively small productivity in these high nutrient/low chlorophyll (HNLC) regions.

A detailed comparison of inverse model export fluxes with estimates based on satellite productivity maps (Schlitzer 2002) has shown that the two methods agree reasonably well in most regions of the South Atlantic except south of $50^{\circ} \mathrm{S}$, where satellite productivity algorithms indicate only weak biological productivity, but where the inverse model requires quite high downward carbon exports to reproduce the measured water column structure of oxygen, phosphate, nitrate and carbon. Schlitzer (2002) argues that the satellite productivity estimates south of $50^{\circ} \mathrm{S}$ might be too low because of a generally poor calibration in this region, and because of undetectable (by satellites) sub-surface chlorophyll patches frequently observed in the Southern Ocean. Comparisons of different satellite algorithms (Campbell et al. 2002) also have identified the Southern Ocean as the region where the results differ most and systematic offsets are largest.

Integrated export fluxes in experiment $\mathrm{A}$ amount to $9840 \mathrm{Tg} \mathrm{C} \mathrm{yr}^{-1}$ (equivalent to $9.84 \mathrm{Gt} \mathrm{C}$ $\mathrm{yr}^{-1}$ ) for the global ocean, $14 \%$ of which (equiva-

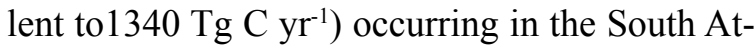
lantic (see Table 2). Experiments $B$ and $C$ have slightly smaller globally integrated carbon exports

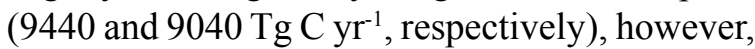
in both cases the POC export in the South Atlantic is almost identical with the result of run A (1320

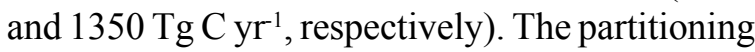
of the South Atlantic carbon export into contributions from the Benguela/Namibia upwelling region and the high productivity region in the southwest Atlantic is quite different for the three experiments: while the Benguela/Namibia upwelling region is dominant in experiment A (558 versus $480 \mathrm{Tg} \mathrm{C}$ $\left.\mathrm{yr}^{-1}\right)$, the southwest Atlantic is shown to be the most important area for downward carbon export in experiments $\mathrm{B}$ and $\mathrm{C}$.

\section{Flux of Particulate Organic Carbon to the Seafloor}

Model particle fluxes at a depth of $2000 \mathrm{~m}$ (a level onto which sediment trap measurements are often extrapolated) are calculated using the model estimates for the parameters $a$ and $b$ and equation (1). As for the global ocean, the carbon fluxes at a depth of $2000 \mathrm{~m}$ in the South Atlantic and two subdomains turn out to be much smaller than the export fluxes (Table 2), confirming results from sediment trap measurements (Martin et al. 1987; Suess 1980) indicating that most of the exported POC is remineralized in the upper $2000 \mathrm{~m}$ of the water column. In experiment $\mathrm{A}$, about $5 \%$ of the exported material arrive at $2000 \mathrm{~m}$, whereas in experiments $\mathrm{B}$ and $\mathrm{C}$ this fraction is slightly larger, approximately amounting to $8 \%$. Taking all three runs into consideration, the POC flux at a depth of $2000 \mathrm{~m}$ in the South Atlantic amounts to $96 \pm 26 \mathrm{Tg} \mathrm{C} \mathrm{yr}^{-1}$. 


\begin{tabular}{|c|c|c|c|}
\hline & $\mathbf{A}$ & B & $\mathrm{C}$ \\
\hline \multicolumn{4}{|l|}{ Export Flux $(133 \mathrm{~m})$} \\
\hline Global Ocean & 9840 & 9440 & 9040 \\
\hline South Atlantic & 1340 & 1320 & 1350 \\
\hline Southwest Atlantic & 480 & 673 & 718 \\
\hline Benguela/Namibia & 558 & 507 & 331 \\
\hline \multicolumn{4}{|l|}{ Flux in $2000 \mathrm{~m}$} \\
\hline Global Ocean & $643(6.5)$ & $911(9.6)$ & $647(7.1)$ \\
\hline South Atlantic & $66(5)$ & $109(8.3)$ & $114(8.4)$ \\
\hline Southwest Atlantic & $20(4.2)$ & $53(7.9)$ & $64(8.9)$ \\
\hline Benguela/Namibia & $28(5)$ & $45(8.9)$ & $28(8.5)$ \\
\hline \multicolumn{4}{|l|}{ Flux to Seafloor } \\
\hline Global Ocean & $602(6.1)$ & $714(7.6)$ & $478(5.3)$ \\
\hline South Atlantic & $62(4.6)$ & $95(7.2)$ & $74(5.5)$ \\
\hline Southwest Atlantic & $30(6.3)$ & $58(8.6)$ & $39(5.4)$ \\
\hline Benguela/Namibia & $20(3.6)$ & $31(6.1)$ & $19(5.7)$ \\
\hline
\end{tabular}

Table 2. Integrated downward fluxes of particulate organic carbon $\left(\mathrm{Tg}_{\left.\mathrm{C} \mathrm{yr}^{-1}\right)}\right)$ for the global ocean, the South Atlantic (as defined by the map domain of Fig. 3), the southwest Atlantic and the Benguela/Namibia high-productivity regions (delineated by $2 \mathrm{~mol} \mathrm{C} \mathrm{m}^{-2} \mathrm{yr}^{-1}$ contour). Results are given for the three model experiments $\mathrm{A}$, $\mathrm{B}$, and $\mathrm{C}$ and for different depths. Values in parenthesis are percentages of respective export fluxes.

Values of POC fluxes to the seafloor have been calculated, again, using parameters $a$ and $b$, and applying equation (1) with the bottom depth $z_{b}$ of each model column. The geographical pattern of the resulting bottom fluxes is shown in Fig. 4, and the integral values for the domains defined above are given in Table 2. The POC fluxes to the seafloor in the South Atlantic (Fig. 4) are clearly dominated by relatively high values (between 0.5 and $3 \mathrm{~mol} \mathrm{C}$ $\mathrm{m}^{-2} \mathrm{yr}^{-1}$ ) along the southwest African and South American coasts. In the open ocean South Atlantic, fluxes are much smaller and generally below $0.1 \mathrm{~mol} \mathrm{C} \mathrm{m}^{-2} \mathrm{yr}^{-1}$. In large regions, values are even smaller than $0.05 \mathrm{~mol} \mathrm{C} \mathrm{m}^{-2} \mathrm{yr}^{-1}$. The overall pattern of bottom POC fluxes differs markedly from the map of export fluxes from the euphotic zone shown in Fig. 3. While in shallow coastal waters and over shelves or the upper continental slopes large fractions of the exported material reaches the bottom, most of the exported POC is remineralized by the time the material reaches the floor in the deep waters of the open ocean. As a consequence, the pronounced high productivity band centered in the southwest Atlantic and stretching eastward is only weakly reflected in the bottom fluxes. The strong decoupling of surface fluxes and bottom signals observed here for POC should equally apply to other materials that are degraded significantly during sinking. Integrated POC fluxes to the seafloor in the South Atlantic amount to $77 \pm 17 \mathrm{Tg}$

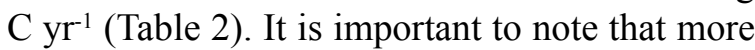
than $80 \%$ of this flux occurs near the coast and on the shelves.

\section{Accumulation of Particulate Organic Carbon in the Sediment}

Model experiment A includes accumulation of particulate organic material in the sediments. It determines the burial fraction $s$ (for definition see above) from signals in the distribution of dissolved oxygen, nutrients and carbon in deep and bottom waters. No a priori geological accumulation rate estimates are used for the present calculations. Comparison of model/data misfits of A with its parent experiment $\mathrm{P}$ (not shown; identical to A except that $\mathrm{P}$ does not include sedimentation but all material reaching the seafloor is remineralized 


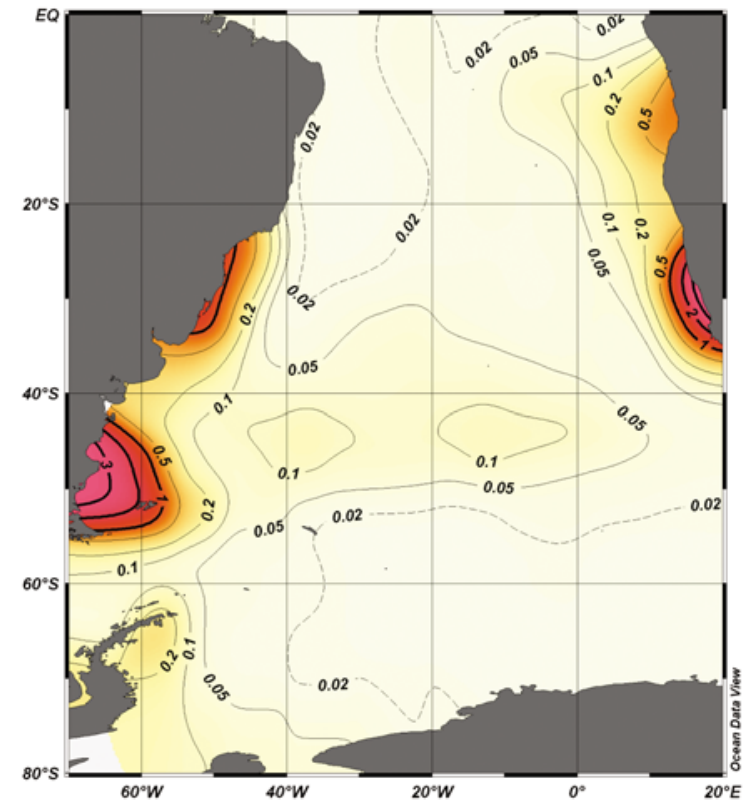

Fig. 4. Flux of particulate organic carbon $\left[\mathrm{mol} \mathrm{C} \mathrm{m}{ }^{-2}\right.$ $\left.\mathrm{yr}^{-1}\right]$ to the seafloor for the model including accumulation of material in the sediment.

in the bottom box) shows that experiment A explains the data slightly better than P. However, this improvement is rather small, suggesting that removal of material in the sediments has a limited effect on the bottom water characteristics, probably because of the small magnitude of the burial fluxes.

Fig. 5 shows the geographical pattern of model POC accumulation in South Atlantic sediments. Comparison with Fig. 4 shows that the accumulation in the sediment is closely linked with the POC fluxes to the seafloor, with about $10 \%$ of the bottom-reaching flux actually being accumulated. Integrated over the entire South Atlantic, the POC

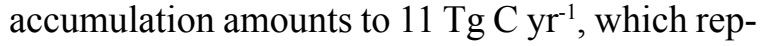
resents only about $0.8 \%$ of the POC exported.

\section{Comparison with Sediment Trap Data}

Sediment trap deployments allow for the direct measurement of downward particle fluxes in the water column, and at the same time provide samples of the material for composition and structure analysis. Within the SFB216 project, a large number of moored sediment traps have been deployed for long periods of time, in order to measure the seasonal cycle of downward particle fluxes and to catch sinking particles. These measurements have been used to estimate export fluxes of particulate organic carbon and nutrients from the euphotic zone into the deep ocean. Additionally, the decrease of particle fluxes with depth has been used to derive particle remineralization rates (Fischer et al. 1988; Fischer et al. 1996; Fischer and Wefer 1996; Neuer et al. 1997; Fischer et al. 2000; Fischer et al. 2002).

However, the reliability of vertical particle fluxes from sediment trap data has been questioned: Horizontal flow velocities in the upper ocean can be relatively high, so that tilting of the trap may occur and/or turbulences may prevent particles to settle into the trap ("under-sampling"; (Baker et al. 1988; Gust et al. 1994; Honjo and Manganini 1996). It has been shown for the deeper and near bottom traps that part of the material collected in the traps was not produced in the overlying water column, but obviously represented reworked suspended material that was transported laterally to the trap's position (Siegel and Deuser 1997; Fischer et al. 2000; Conte et al. 2001). This "over-sampling" appeared to be strongest in the vicinity of sloping bathymetry and close to the ocean bottom.

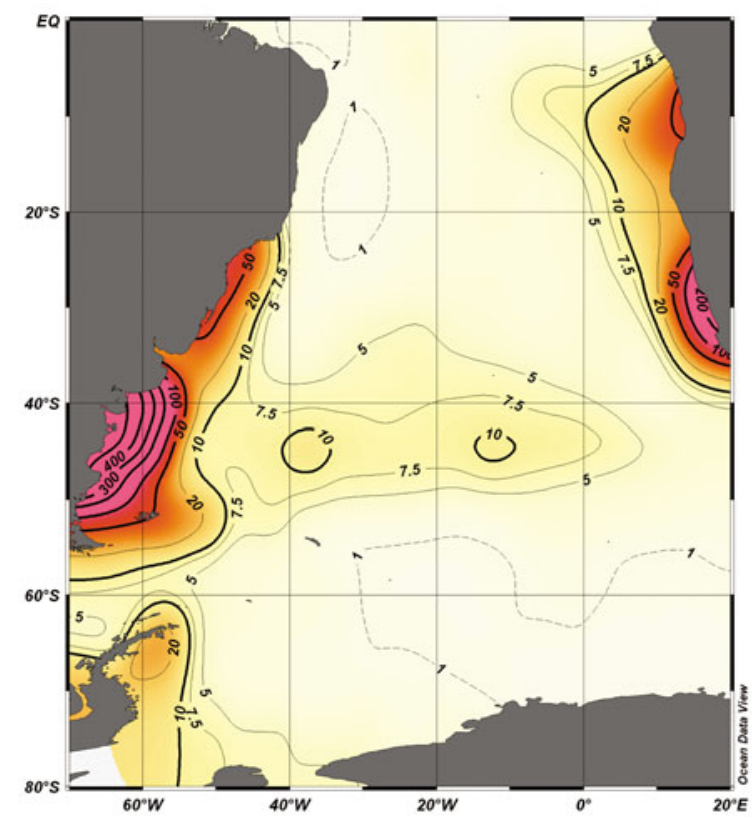

Fig. 5. Accumulation flux of particulate organic carbon $\left[\mathrm{mmol} \mathrm{C} \mathrm{m} \mathrm{yr}^{-1}\right]$ in the sediment. 
Sampling efficiencies of sediment traps have been estimated using budgets of radionuclides (Bacon et al. 1985; Buesseler 1991; Buesseler et al. 1994) or aluminum fluxes (Walsh et al. 1988). At present, the calculation of ${ }^{230} \mathrm{Th}$ budgets seems to be the most reliable calibration method. ${ }^{230} \mathrm{Th}$ is produced in the water column by the decay of ${ }^{234} \mathrm{U}$ and is highly particle reactive. Sinking particles scavenge ${ }^{230} \mathrm{Th}$, and the flux at a given depth must (on time scales of months to years) balance the production rate in the overlying water column. Therefore the ${ }^{230} \mathrm{Th}$ flux into a sediment trap should equal the amount of ${ }^{230} \mathrm{Th}$ produced above the trap. This quantity increases with depth and is well known, because the concentration of the parent nuclide ${ }^{234} \mathrm{U}$ in seawater is constant and well determined. If the measured ${ }^{230} \mathrm{Th}$ flux in a sediment trap is smaller than the theoretical value, part of the downward particle flux is obviously missed by the trap and it is therefore "under-trapping". If on the other hand, the measured ${ }^{230} \mathrm{Th}$ flux is larger than expected, the additional ${ }^{230} \mathrm{Th}$ can only originate from lateral input, and the trap obviously overestimates the vertical flux ("over-trapping"). Recently, Scholten et al. (2001) found that ${ }^{230}$ Th fluxes indicate low trapping efficiencies in shallow traps (at the average 40\%). In deep traps, they found ambiguous results, some traps showing larger as well as smaller particle fluxes than have been calculated from ${ }^{230} \mathrm{Th}$ budgets.

Here we compare direct flux measurements from sediment traps with the downward particle fluxes of the inverse model. As described above, the model POC fluxes are determined on the basis of long-term steady state oxygen, nutrient and carbon budgets, and thus provide estimates of downward fluxes of carbon and nutrients that are independent of sediment trap measurements. Figure 6 shows the positions of the sediment traps from the SFB216 project in the South and Equatorial Atlantic considered here. Most traps are long-term deployments of at least one year or more. Annual mean POC fluxes have been calculated from the original data (see Usbeck 1999 for details of the averaging procedure), values of which are listed in Table 3.

Figures 7 and 8 show model POC fluxes versus the annual average POC fluxes obtained from

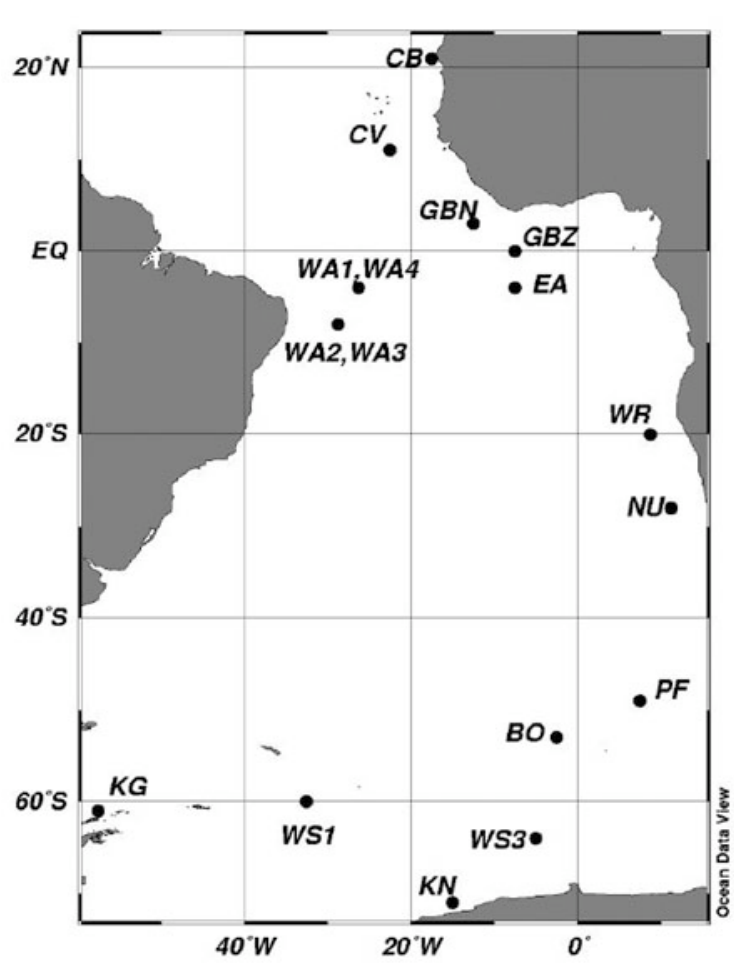

Fig. 6. Positions of sediment traps used for the present study.

the sediment traps. Altogether, it is worth emphasizing that the model fluxes are of the same order of magnitude as the sediment trap measurements. However, systematic deviations of model fluxes from the trap measurements do exist. In the shallow traps $(<1000 \mathrm{~m}$ depth; Fig. 7$)$, model POC fluxes are systematically higher than in measurements performed at all positions in the South- and Equatorial Atlantic. Model POC fluxes lie well above the 1:1-relation in Fig. 7. The ratios of trap fluxes relative to model fluxes range from 0.03 (WS1) to 0.85 $(\mathrm{PF})$, with an average ratio of 0.46 . Thus, on average, the model fluxes at the sediment trap positions are about a factor of 2 higher than the trap measurements. POC fluxes higher than $0.6 \mathrm{~mol} \mathrm{~m}^{-2} \mathrm{yr}^{-}$ ${ }^{1}$ are found in the model calculations, but no trap in the South Atlantic showed fluxes of this size.

For the deep traps ( $>1000 \mathrm{~m}$ depth; Fig. 8$)$, model POC fluxes are lower than measurements. With WR and CV being the only exceptions, all other model fluxes lie below the 1:1 relation. The ratios of trap and modeled POC fluxes range from 0.93 (WR) to 18.1 (GBZ), with an average of 5.1, i.e. 


\begin{tabular}{|c|c|c|c|c|c|}
\hline Trap & Lat $\left({ }^{\circ} \mathrm{N}\right)$ & Lon $\left({ }^{\circ} \mathrm{E}\right)$ & Depth $(\mathrm{m})$ & Duration (days) & POC Flux \\
\hline & & & & & \\
\hline KN1 & -71 & -12 & 250 & 53 & 0.1583 \\
\hline WS3 & -65 & -3 & 360 & 368 & 0.1942 \\
\hline KG1 & -62 & -58 & 1600 & 360 & 0.3583 \\
\hline WS1 & -62 & -35 & 900 & 418 & 0.0025 \\
\hline BO1 & -54 & -3 & 453 & 460 & 0.225 \\
\hline PF3 & -50 & 6 & 700 & 366 & 0.2808 \\
\hline NU2 & -29 & 13 & 768 & 361 & 0.5762 \\
\hline WR21 & -20 & 9 & 1654 & 360 & 0.3142 \\
\hline WA3u & -8 & -28 & 671 & 350 & 0.0792 \\
\hline WA31 & -8 & -28 & 5031 & 350 & 0.0246 \\
\hline WA41 & -4 & -26 & 4555 & 375 & 0.0813 \\
\hline EA8m & -6 & -9 & 1833 & 296 & 0.1967 \\
\hline GBZ51 & -2 & -10 & 3382 & 360 & 0.1917 \\
\hline GBN31 & 2 & -11 & 3965 & 361 & 0.181 \\
\hline CV1u,CV2u & 11.5 & -21 & 1000 & 679 & 0.2239 \\
\hline CV11,CV21 & 11.5 & -21 & 4500 & 679 & 0.106 \\
\hline CB2,CB3 & 21 & -20 & 3525 & 718 & 0.5042 \\
\hline
\end{tabular}

Table 3. Long-term mean downward fluxes of POC $\left(\mathrm{mol} \mathrm{C} \mathrm{m}^{-2} \mathrm{yr}^{-1}\right)$ from sediment trap measurements. Trap deployment was for one or two years in most cases.

measured POC fluxes are about a factor 5 larger than modeled fluxes. The systematic deviation of model fluxes and deep sediment trap data seems to be much larger than for the shallow traps, but the absolute deviations are in fact smaller. POC fluxes in the very deep ocean are relatively small, and additions of laterally transported, re-suspended material in the sediment trap can affect the ratios considerably, even if these additions are small in terms of absolute magnitude. Small systematic errors in the model deep ocean particle fluxes possibly due to deviations from the Martin-type functional relationship (1) in the real ocean, cannot be ruled out completely and provide an alternative explanation for the model/observation mismatch below the depth of $1000 \mathrm{~m}$.

To investigate whether the systematic deviations between model and the sediment traps described above (traps lower than model in upper $1000 \mathrm{~m}$ of the water column; traps higher than model below $1000 \mathrm{~m}$ ) are robust, an extension of the model was developed, which allows to drive the model particle fluxes towards measured fluxes. Various experiments were performed to test whether it is possible to obtain model particle fluxes closer to the sediment trap data, i.e. to reduce model/trap misfits in Figs. 7 and 8. The sediment trap data were included as soft constraints by adding a new term to the model cost function that penalizes deviations of model fluxes from trap data. Different model runs with different weight factors for the new cost function term were conducted. None, of these experiments was considered successful because systematic model/data misfits persisted in all cases. For the run with a very large weight on the model/trap penalty term, the model POC fluxes at the trap locations agreed rather well with the trap data, however, the model adjustment was local (singularity at the trap locations only) and the high model fluxes in the upper water column persisted at all other grid-points. Another experiment was conducted to enforce the trap data in the model over larger horizontal distances by applying smoothness constraints. This run showed that the smaller trap fluxes in the upper water column were inconsistent with the measured distributions of oxygen, nutrients and carbon in the ocean, because enforcing these fluxes over great areas led to un- 


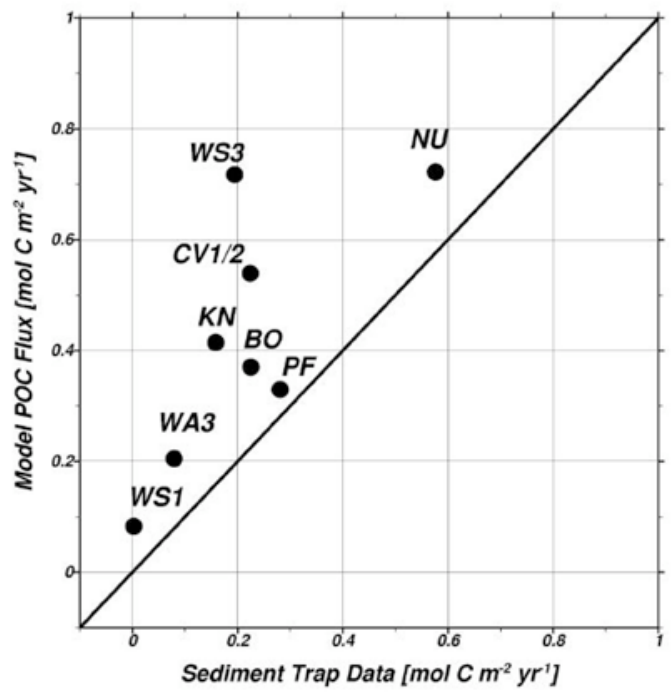

Fig. 7. POC model fluxes versus sediment trap data for traps shallower than $1000 \mathrm{~m}$. The solid line is the $1: 1 \mathrm{re-}$ lation.

realistic simulations for oxygen, nutrients and carbon (Usbeck et al. 2003).

\section{Summary and Discussion}

The present model calculations have shown that the strong and systematic traces of marine biogeochemical processes found in the distributions of dissolved oxygen, nutrients and carbon in the ocean can be used by a coupled physical/biogeochemical model to determine rate-constants as well as biogeochemical carbon and nutrient fluxes. The adjoint method has proven to be an efficient tool to drive the model towards the observations. The level of agreement between model simulation and observations achieved by the adjoint method is unmatched by any other biogeochemical model. Given that more data of even better quality will be available in the near future, the success of this study should motivate more inverse-type evaluations of marine biogeochemical cycles in the future.

For the global ocean, the three model experiments discussed here yielded integrated export fluxes of POC lying between 9040 and $9840 \mathrm{Tg} \mathrm{C}$ $\mathrm{yr}^{-1}$. This is in relatively good agreement with export fluxes found in other global biogeochemical models (8000 to $12,000 \mathrm{Tg} \mathrm{C} \mathrm{yr}^{-1}$; (Najjar et al. 1992; Anderson and Sarmiento 1995; Six and Maier-Reimer 1996; Yamanaka and Tajika 1997; Popova et al. 2000)) and with global estimates from

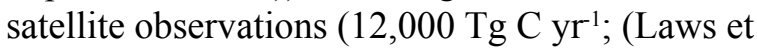
al. 2000)). Lower global export fluxes between 2000 and $4000 \mathrm{Tg} \mathrm{C} \mathrm{yr}^{-1}$ as obtained by simple box models (Broecker and Peng 1982; Sarmiento and Toggweiler 1984; Siegenthaler and Wenk 1984) are found to be incompatible with observed nutrient and oxygen fields (Schlitzer 2000).

The contribution of the South Atlantic $\left(70^{\circ} \mathrm{W}\right.$ to $20^{\circ} \mathrm{E} ; 80^{\circ} \mathrm{S}$ to Equator; see map domain in Fig. 3) to the POC export amounts to $1350 \mathrm{Tg} \mathrm{C} \mathrm{yr}^{-1}$ (ca. $14 \%$ of global integral) and occurs mainly in the Benguela/Namibia coastal upwelling region and in a westward intensified zonal band that roughly follows the course of the ACC and Polar Front (ca. $52^{\circ} \mathrm{S}$ ). Comparison with satellite derived productivity maps (Schlitzer 2002) has shown rather good agreement north of $50^{\circ} \mathrm{S}$, however, there is a significant difference south of this line, with the model export fluxes being about twice as large as the satellite derived values. Because of unrealistic oxygen, nutrients and carbon simulations, the lower satellite estimates could not be reproduced by the

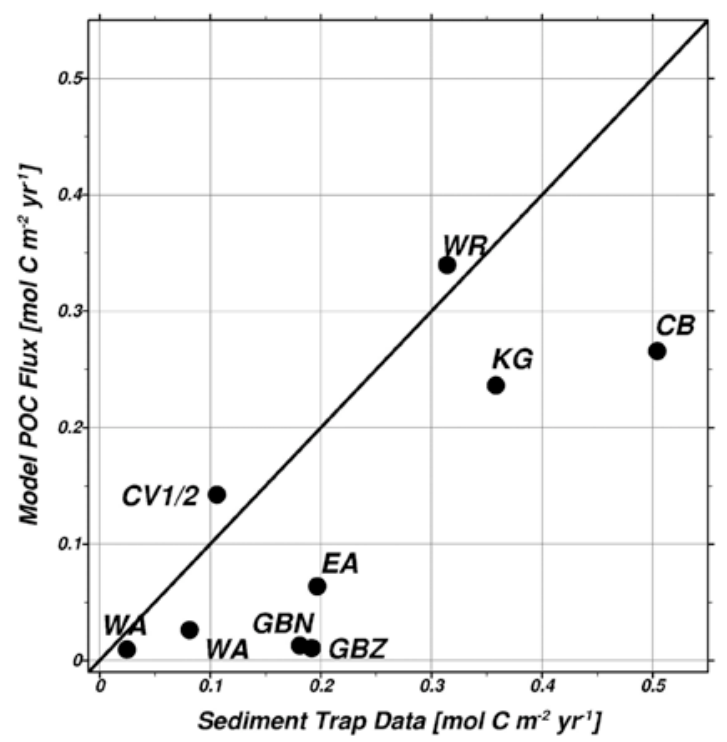

Fig. 8. POC model fluxes versus sediment trap data for traps deeper than $1000 \mathrm{~m}$. The solid line is the $1: 1$ relation. 
model. Schlitzer (2002) argues that satellite based productivity estimates in the Southern Ocean might be too low, because satellites miss the productivity associated with frequently observed sub-surface chlorophyll patches and because of poor calibration with only few in- situ data in this region. This seems to be confirmed by the large variability and significant systematic offsets between different satellite productivity algorithms, found especially in the Southern Ocean (Campbell et al. 2002).

In the model, POC fluxes rapidly decrease with depth, and at a depth of $2000 \mathrm{~m}$ amount to $96 \pm 26$ $\mathrm{Tg} \mathrm{C} \mathrm{yr}{ }^{-1}$ only. The integrated flux to the seafloor is of comparable magnitude, $77 \pm 17 \mathrm{Tg} \mathrm{C} \mathrm{yr}^{-1}$, and concentrated in coastal and shelf regions. This pattern is very similar to the map of benthic oxygen consumption of Jahnke (1996), which also has highest rates along the southwest African coast and on the Patagonian shelf. Jahnke's map also shows the weak benthic imprint of the high open ocean surface productivity between $35^{\circ} \mathrm{S}$ and $50^{\circ} \mathrm{S}$. Not only are the patterns similar, the numerical values also agree remarkably well $\left(>0.5 \mathrm{~mol} \mathrm{C} \mathrm{m}^{-2} \mathrm{yr}^{-1}\right.$ respectively $\mathrm{mol} \mathrm{O}_{2} \mathrm{~m}^{-2} \mathrm{yr}^{-1}$ along the Namibian coast and $<0.3 \mathrm{~mol} \mathrm{C} \mathrm{m}^{-2} \mathrm{yr}^{-1}$ in the open ocean of the South Atlantic). It is noteworthy that, in the model, more than $90 \%$ (for experiment $\mathrm{A} ; 100 \%$ for $\mathrm{B}$ and $\mathrm{C}$ ) of the carbon flux to the seafloor is respired, leading to the consumption of oxygen as measured by Jahnke. A good agreement of model benthic fluxes is also obtained when comparing them with the release of benthic phosphate and nitrate as described by Hensen et al. (1998) and Zabel et al. (1998) (geographical pattern and numerical values; conversion using Redfield values $\mathrm{C} / \mathrm{P}=106, \mathrm{C} / \mathrm{N}=6.6$ ).

The globally integrated burial of POC resulting

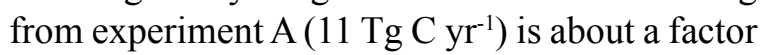
of 1.5 higher than the estimate of Broecker and Peng (1993) for present-day carbon cycling. Sundquist (1985) summarized estimates from various sources varying by a factor of more than 100 . The total accumulation of organic carbon derived from the adjoint model is well in the range of these estimates and comparably close to Broecker and Peng's (1993) most recently published value. The global mean relative (to export flux) accumulation rate, or preservation efficiency, of organic carbon is within the range proposed by Berger (1989) $(0.88 \%$ vs. $0.3-3 \%)$.

The comparison of model downward POC fluxes with direct measurements using sediment traps has revealed large, systematic discrepancies that could not be reconciled. At all shallow trap positions presented here, the mean model particle fluxes are higher as compared to the sediment trap data. This is consistent with independent results from ${ }^{230}$ Th calibrations (Buesseler 1991; Scholten et al. 2001) and suggests that sediment traps tend to underestimate vertical particle fluxes at shallow water depths. For the deep traps, radionuclide calibrations indicate over-trapping as well as undertrapping (Scholten et al. 2001), whereas the model results shown in Fig. 8 suggest that overestimation of deep POC fluxes by traps might be a common problem. Lateral input of re-suspended material in the vicinity of sloping bathymetry or near the bottom is a process that could explain an over-sampling by traps. This has also been suggested by Fischer et al. (2000), Abelmann and Gersonde (1991), and Siegel and Deuser (1997).

Comparison of POC fluxes to the seafloor and POC burial in the sediment (Figs 4 and 5) with the POC export from the euphotic zone (Fig. 3) reveals significantly different patterns and shows that major surface productivity features (especially in openocean areas over deep water) are not, or only weakly, represented in bottom fluxes. This is attributable to the relatively rapid remineralization of POC with depth- that allows significant portions of the exported material to reach the seafloor in coastal and shelf regions, but leaves little material in deep-sea sediments. Reconstructing surface productivity from sediment accumulation rates, which involves the mapping of (small) bottom signals to much larger surface fluxes, therefore requires a good knowledge of the remineralization in the water column and sediment. The projection of sediment trap data to a common depth level, which is commonly performed to produce maps of downward particle fluxes, also relies on a known depth dependence of the POC flux. It is common practice to use formulations of POC flux versus depth from the literature (Bishop 1989; Martin et al. 1987; Suess 1980) for this purpose. However, these approaches employ different function types and pa- 
rameters and yield projected fluxes that are significantly different, indicating that remineralization and depth-dependence of POC in the ocean is actually poorly known. Results of Usbeck et al. (2002) suggest that remineralization scale heights might vary regionally and that none of the published formulations are universally applicable.

\section{Acknowledgements}

We acknowledge inspiring scientific discussions with Richard Jahnke, Mike Behrenfeld, Ken Buesseler, Michiel Rutgers van der Loeff, Peter Müller and Susanne Neuer. A detailed and constructive review by Andreas Oschlies helped to improve the manuscript. This work was funded by the Deutsche Forschungsgemeinschaft (Sonderforschungsbereich 261, publication no. 376). Data are available under www.pangaea.de/ Projects/SFB261.

\section{References}

Abelmann A, Gersonde R (1991) Biosiliceous particle flux in the Southern Ocean. Mar Chem 35: 503-536

Anderson LA, Sarmiento J (1995) Global ocean phosphate and oxygen simulations. Glob Biogeochem Cycl 9: 621-636

Anderson TR, le B Williams PJ (1999)A one-dimensional model of dissolved organic carbon cycling in the water column incorporating combined biologicalphotochemical decomposition. Glob Biogeochem Cycl 13: 337-349

Antoine D, Andre J-M, Morel A(1996) Oceanic primary production 2. Estimation at global scale from satellite (coastal zone color scanner) chlorophyll. Glob Biogeochem Cycl 10: 57-69

Arrigo KR, Worthen D, Schnell A, Lizotte MP (1998) Primary production in Southern Ocean waters. J Geophys Res 103: 15587-15600

Bacon MP, Huh C-A, Fleer AP, Deuser WG (1985) Seasonality in the flux of natural radionuclides and plutonium in the deep Sargasso Sea. Deep-Sea Res 32: $273-286$

Baker ET, Milburn HB, Tennant DA (1988) Field assessment of sediment trap efficiency under varying flow conditions. J Mar Res 46: 573-592

Behrenfeld MJ, Falkowski PG (1997) Photosynthetic rates derived from satellite-based chlorophyll concentration. Limnol Oceanogr 42: 1-20
Berger WH (1989) Appendix. Global maps of ocean productivity. In: Berger WH, Smetacek VS, Wefer G (eds) Productivity of the Ocean: Present and Past. J Wiley \& Sons, Chichester, pp 429-455

Berner E, Berner RA (1996) Global Environment: Water, Air, and Geochemical Cycles. Prentice Hall, New Jersey

Bishop JKB (1989) Regional extremes in particular matter composition and flux: Effects on the chemistry of the ocean interior. In: Berger WH, Smetacek VS, Wefer G (eds) Productivity of the Oceans: Present and Past. J Wiley \& Sons, Chichester, pp 117-137

Broecker WS, Peng T-H (1982) Tracers in the Sea. Lamont-Doherty Geological Observatory, Columbia University, Palisades, NY

Broecker WS, Blanton S, Smethie W, Östlund G (1991) Radiocarbon decay and oxygen utilization in the deep Atlantic Ocean. Glob Biogeochem Cycl 5: 87117

Broecker WS, Peng T-H (1993) Greenhouse puzzles. Lamont- Doherty Earth Observatory of Columbia University, Palisades, NY

Buesseler KO (1991) Do upper-ocean sediment traps provide an accurate record of particle flux? Nature 353: 420-423

Buesseler KO, Michaels AF, Siegel DA, Knap H (1994) A three dimensional time-dependent approach to calibrating sediment trap fluxes. Glob Biogeochem Cycl 8: 179-193

Campbell J, Antoine D, Armstrong R, Arrigo K, Balch W, Barber R, Behrenfeld M, Bidigare R, Bishop J, Carr M-E (2002) Comparison of algorithms for estimating ocean primary production from surface chlorophyll, temperature and irradiance. Glob Biogeochem Cycl 16: DOI 10.1029/2001GB001444

Codispoti LA, Christensen JP (1985) Nitrification, denitrification and nitrous oxide cycling in the eastern tropical south Pacific Ocean. Mar Chem 16: 277300

Codispoti LA, Friederich GE, Packard TT, Glover HE, Kelly PJ, Spinrad RW, Barber RT, Elkins JW, Ward BB, Lipschultz F, Lostaunau N (1986) High nitrite levels off nothern Peru: A signal of instability in the marine denitrification rate. Science 233: 1200-1202

Conte MH, Ralph N, Ross EH (2001) Seasonal and interannual variability in deep ocean particle fluxes at the Oceanic Flux Program (OFP)/Bermuda Atlantic Time Series (BATS) site in the western Sargasso Sea near Bermuda. Deep-Sea Res Part II: Topical Studies in Oceanography 48: 1471-1505

de Baar HJW, de Jong JTM, Bakker DCE, Löscher BM, Veth C, Bathmann U, Smetacek V (1995) Importance 
of iron for plankton blooms and carbon dioxide drawdown in the Southern Ocean. Nature 373: 412414

de las Heras M, Schlitzer R (1999) On the importance of intermediate water flows for the global ocean overturning. J Geophys Res 104: 15515-15536

Deuser WG, Jickells TD, King P, Commeau JA (1995) Decadal and annual changes in biogenic opal and carbonate fluxes to the deep Sargasso Sea. DeepSea Res 42: 1923-1932

Fasham MJR, Ducklow HW, McKelvie SM (1990) A nitrogen-based model of plankton dynamics in the oceanic mixed layer. J Mar Res 48: 591-639

Fischer G, Wefer G (1996) Long-term observation of particle fluxes in the eastern Atlantic: Seasonality, changes of flux with depth and comparison with the sediment record. In: Siedler G, Wefer G, Berger WH, Webb D (eds) The South Atlantic: Present and Past Circulation. Springer, Berlin, pp 325-344

Fischer G, Fütterer D, Gersonde R, Honjo S, Ostermann D, Wefer G (1988) Seasonal variability of particle flux in the Weddell Sea and its relation to ice cover. Nature 335: 426-428

Fischer G, Donner B, Ratmeyer V, Davenport R, Wefer G (1996) Distinct year-to-year particle flux variations off Cape Blanc during 1988-1991: Relation to $\delta^{18} \mathrm{O}-$ deduced sea-surface temperatures and trade winds. J Mar Res 54: 73-98

Fischer G, Ratmeyer V, Wefer G (2000) Organic carbon fluxes in the Atlantic and the Southern Ocean: Relationship to primary production compiled from satellite radiometer data. Deep-Sea Res II 47: 1961-1997

Fischer G, Gersonde R, Wefer G (2002) Organic carbon, biogenic silica and diatom fluxes in the marginal winter sea-ice zone and in the Polar Front Region: interannual variations and differences in composition. Deep-Sea Res Part II: Topical Studies in Oceanography 49: 1721-1745

Gruber N, Sarmiento JL (1997) Global patterns of marine nitrogen fixation and denitrification. Glob Biogeochem Cycl 11:235-266

Gust G, Michaels AF, Johnson RG, Deuser WG, Bowles W (1994) Mooring line motions and sediment trap hydromechanics: In situ intercomparison of three common deployment designs. Deep-Sea Res 41: 831857

Hansell DA, Carlson CA (1998) Net community production of dissolved organic carbon. Glob Biogeochem Cycl 12: 443-453

Hensen C, Landenberger H, Zabel M, Schulz HD (1998) Quantification of diffusive benthic fluxes of nitrate, phosphate and silicate in the southern Atlantic
Ocean. Glob Biogeochem Cycl 12: 193-210

Hestenes MR (1975) Optimization Theory. J Wiley \& Sons, Inc, New York

Honjo S, Manganini SJ, Cole JJ (1982) Sedimentation of biogenic matter in the deep ocean. Deep-Sea Res 29: 609-625

Honjo S, Manganini SJ (1996) Annual biogenic particle fluxes to the interior of the North Atlantic Ocean studied at $34^{\circ} \mathrm{N} 21^{\circ} \mathrm{W}$ and $48^{\circ} \mathrm{N} 21^{\circ} \mathrm{W}$. In: Milliman JD (ed) Topical Studies in Oceanography JGOFS: The North Atlantic Bloom Experiment. Pergamon Press, Oxford, pp 587-607

Howell EA, Doney SC, Fine RA, Olson DB (1997) Geochemical estimates of denitrification in the Arabian Sea and the Bay of Bengal during WOCE. Geoph Res Lett 24: 2549-2552

Jahnke RA (1996) The global ocean flux of particulate organic carbon: areal distribution and magnitude. Glob Biogeochem Cycl 10: 71-88

Jenkins WJ (1982) Oxygen utilization rates in north Atlantic subtropical gyre and primary production in oligotrophic systems. Nature 300: 246-248

Jenkins WJ, Goldman JC (1985) Seasonal oxygen cycling and primary production in the Sargasso Sea. J Mar Res 43: 465-491

Jenkins WJ (1987) $3 \mathrm{H}$ and $3 \mathrm{He}$ in the Beta Triangle: Observations of gyre ventilation and oxygen utilization rates. J Phys Oceanogr 17: 763-783

Kirchman DL, Suzuki Y, Garside C, Ducklow HW (1991) High turnover rates of dissolved organic carbon during a spring phytoplankton bloom. Nature 352: 612-614

Laws EA, Falkowski PG, Smith WO, Ducklow H, McCarthy JJ (2000) Temperature effects on export production in the open ocean. Glob Biogeochem Cycl 14: $1231-1246$

Lerman A (1980) Controls on river water composition and mass balance of river systems. In: Martin JM (ed) River Inputs to Ocean Systems. J Wiley \& Sons, New York, pp 1 - 12

Longhurst A, Sathyendranath S, Platt T, Caverhill C (1995) An estimate of global primary production in the ocean from satellite radiometer data. J Plankt Res 17: $1245-1271$

Maier-Reimer E (1993) Geochemical cycles in an ocean general circulation model. Preindustrial tracer distributions. Glob Biogeochem Cycl 7: 645-677

Martin JH, Knauer GA, Karl DM, Broenkow WW (1987) VERTEX: Carbon cycling in the northeast Pacific. Deep-Sea Res 34: 267-285

Najjar RG, Sarmiento JL, Toggweiler JR (1992) Downward transport and fate of organic matter in the ocean: 
simulations with a general circulation model. Glob Biogeochem Cycl 6: 45-76

Neuer S, Ratmeyer V, Davenport R, Fischer G, Wefer G (1997) Deep water particle flux in the Canary Island region: seasonal trends in relation to long-term satellite derived pigment data and lateral sources. DeepSea Res I: Oceanographic Research Papers 44: 14511466

Nierenberg WA, Nowlin WD, Jr. (1985) Physical, chemical and in situ CTD data from the AJAX Expedition aboard RV KNORR. Scripps Inst. Oceanography, La Jolla, CA, SIO Reference 85-24

Popova EE, Ryabchenko VA, Fasham MJR (2000) Biological pump and vertical mixing in the Southern Ocean: Their impact on atmospheric $\mathrm{CO}_{2}$. Glob Biogeochem Cycl 14: 477-498

Reid JL (1986) On the total geostrophic circulation of the South Pacific Ocean: Flow patterns, tracers, and transports. Prog Oceanogr 16: 1-61

Reid JL (1997) On the total geostrophic circulation of the Pacific Ocean: Flow patterns, tracers, and transports. Prog Oceanogr 39: 263-352

Riley GA (1951) Oxygen, phosphate, and nitrate in the Atlantic Ocean. Bull Bingham Oceanogr Coll 13: 1124

Rintoul S (1991) South Atlantic interbasin exchange. J Geophys Res 96: 2675-2692

Rintoul S, Wunsch C (1991) Mass, heat, oxygen and nutrient fluxes and budgets in the North Atlantic Ocean. Deep-Sea Res 38 (suppl): 355-377

Sarmiento JL, Toggweiler JR (1984) A new model for the role of the oceans in determining atmospheric $\mathrm{pCO}_{2}$. Nature 308: 621-624

Sarmiento JL, Monfray P, Maier-Reimer E, Aumont O, Murnane R, Orr J (2000) Sea-air CO2 fluxes and carbon transport: a comparison of three ocean general circulation models. Glob Biogeochem Cycl 14: 1267 1281

Schlitzer R (1993) Determining the mean, large-scale circulation of the Atlantic with the adjoint method. J Phys Oceanogr 23: 1935-1952

Schlitzer R (1995) An adjoint model for the determination of the mean oceanic circulation, air-sea fluxes and mixing coefficients. Alfred-Wegener-Institut, Bremerhaven, Ber Polarforsch 156

Schlitzer R (1996) Mass and heat transports in the South Atlantic derived from historical hydrographic data. In: Siedler G, Wefer G, Berger WH, Webb D (eds) The South Atlantic: Present and Past Circulation. Springer, Berlin, pp 305-323

Schlitzer R (2000) Applying the adjoint method for global biogeochemical modeling. In: Kasibhatla P,
Heimann M, Hartley D, Mahowald N, Prinn R, Rayner $\mathrm{P}$ (eds) Inverse Methods in Global Biogeochemical Cycles. AGU Geophys. Monograph Series, Vol. 114, pp 107-124

Schlitzer R (2002) Carbon export fluxes in the Southern Ocean: Results from inverse modeling and comparison with satellite based estimates. Deep-Sea Res II 49: $1623-1644$

Scholten JC, Fietzke J, Vogler S, Rutgers van der Loeff MM, Mangini A, Koeve W, Waniek J, Stoffers P, Antia A, Kuss J (2001) Trapping efficiencies of sediment traps from the deep Eastern North Atlantic: The 230Th calibration. Deep-Sea Res II: Topical Studies in Oceanography 48: 2383-2408

Siegel DA, Deuser WG (1997) Trajectories of sinking particles in the Sargasso Sea: Modeling of statistical funnels above deep-ocean sediment traps. DeepSea Res I 44: 1519-1541

Siegenthaler U, Wenk T (1984) Rapid atmospheric CO variations and ocean circulation. Nature 308: 624-626

Six KD, Maier-Reimer E (1996) Effects of plankton dynamics on seasonal carbon fluxes in an ocean general circulation model. Glob Biogeochem Cycl 10: 559583

Suess E (1980) Particulate organic carbon flux in the oceans-surface productivity and oxygen utilization. Nature 288: 260-263

Sundquist ET (1985) Geological perspectives on carbon dioxide and the carbon cycle. In: Sundquist E, Broecker W (eds) The Carbon Cycle and Atmospheric $\mathrm{CO}_{2}$ : Natural Variations Archean to Present. AGU Geophysical Monograph, Washington DC, vol 32, pp 5-59

Thacker WC, Long RB (1988) Fitting dynamics to data. J Geophys Res 93: 1227-1240

Usbeck R (1999) Modeling of marine biogeochemical cycles with an emphasis on vertical particle fluxes. Alfred Wegener Institute, Bremerhaven, Rep Polar Res 332, $105 \mathrm{p}$

Usbeck R, Loeff MRvd, Hoppema M, Schlitzer R (2002) Shallow remineralization in the Weddell Gyre. Geochem Geophys Geosyst 3: 10.1029/2001GC000182

Usbeck R, Schlitzer R, Fischer G, Wefer G (2003) Particle fluxes in the ocean: Comparison of sediment trap data with results from inverse modeling. J Mar Sys 39: $167-183$

Volk T, Hoffert MI (1985) Ocean carbon pumps: analysis of relative strengths and efficiencies in oceandriven atmospheric $\mathrm{CO}_{2}$ changes. In: Sundquist ET, Broecker WS (eds) The Carbon Cycle and Atmospheric $\mathrm{CO}_{2}$ : Natural Variations Archean to Present. AGU Geophysical Monograph 32, Washington DC, 
pp 99-110

Walsh I, Dymond J, Collier R (1988) Rates of recycling of biogenic components of settling particles in the ocean derived from sediment trap experiments. DeepSea Res 35: 43-58

Wefer G, Suess E, Balzer W, Liebezeit G, Müller PJ, Ungerer CA, Zenk W (1982) Fluxes of biogenic components from sediment trap deployment in circumpolar waters of the Drake Passage. Nature 299: 145-147

Whitworth T, III, Nowlin WD Jr (1987) Water masses and currents of the southern ocean at the Greenwich meridian. J Geophys Res 92: 6462-6476

WOCE Data Products Committee (2000) WOCE global data, version 2.0. WOCE Intern. Project Office,
Southampton, UK, 171/00

Yamanaka Y, Tajika E (1996) The role of the vertical fluxes of particulate organic matter and calcite in the oceanic carbon cycle: Studies using an ocean biogeochemical general circulation model. Glob Biogeochem Cycl 10: 361-382

Yamanaka Y, Tajika E (1997) Role of dissolved organic matter in the marine biogeochemical cycle: Studies using an ocean biogeochemical general circulation model. Glob Biogeochem Cycl 11: 599-612

Zabel M, Dahmke A, Schulz HD (1998) Regional distributions of diffusive phosphate and silicate fluxes through the sediment-water interface: The eastern South Atlantic. Deep-Sea Res I 45: 277-300 